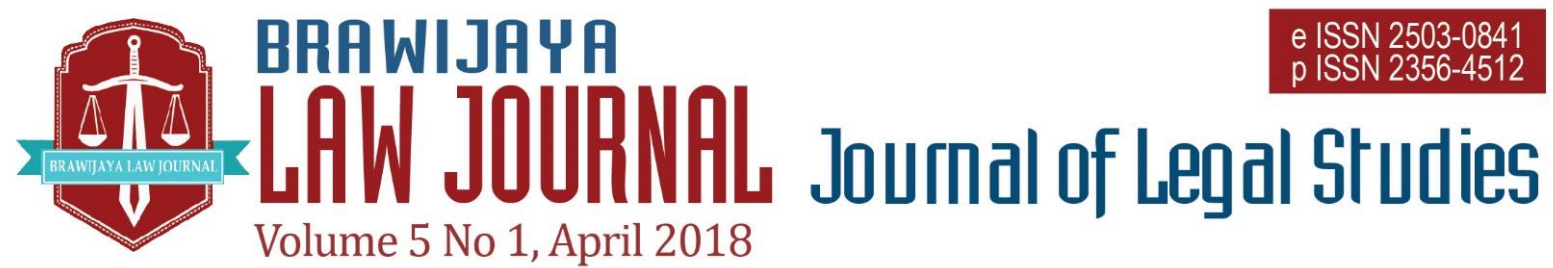

Nationally Accredited No. 32a/E/KPT/2017 Dated 26th April 2017

This work is licensed under a Creative Commons Attribution-NonCommercial 4.0 International License

\title{
The Roles of International Law on Technological Advances
}

\author{
Emmy Latifah ${ }^{1}$, Moch Najib Imanullah ${ }^{2}$ \\ ${ }^{1}$ Faculty of Law, Universitas Sebelas Maret \\ E-mail : emmy.latifah@staff.uns.ac.id \\ ${ }^{2}$ Faculty of Law, Universitas Sebelas Maret \\ E-mail : najibimanullah@staff.uns.ac.id
}

Submitted : 2018-02-18 | Accepted : 2018-04-02

\begin{abstract}
The study focuses on the roles of International Law in responding to the technological advances, particularly examining the International Law as a regulator on emerging technology. The technological advances, especially in the means and method of war and environmental issues, have been contributing to the development of International Law. It is a normative legal research using the secondary data including primary and secondary legal materials. While the primary legal materials consist of all the international agreement related to the development of technology both directly and indirectly, secondary ones included the references having correlation and support to the issues. The technique of analysis data used legal interpretation. The study concludes that as a regulator of technological advances, International Law has a role to play in regulating its development. Many facts showed that International Law has capability to respond to the challenges. However, the scope and application of International Law is subject to a number of limitations inherent the nature of International Law itself.
\end{abstract}

Keywords: $\quad$ roles of international law, technological advances.

\section{INTRODUCTION}

Scientific and technological advances are driving rapid global change. The waves of technological change, driven by inventions ranging from steam power to electricity to the automobile, have driven

Jeffry D. Sachs, The Age of Sustainable Development, (Columbia University Press, 2015), 82.

2 Historians recorded that the world has undergone various phases of industrial revolution on the period of 1760-1830. Starting from the first industrial revolution that mechanized production, to the second one that led to mass production, to economic development and social transformation throughout history. ${ }^{1}$ Klaus Schwab has argued that we are now in the fourth industrial revolution", where " a fusion of technologies ... is blurring the lines between the physical, digital, and biological

the third one that automated production. For more detail, see Julian Hoppit, 'Understanding the Industrial Revolution', (1987) 30 1, The Historical Journal, 211-224; Jan De Vries, 'The Industrial Revolution and the Industrious Revolution', (1994) 54 2, The Journal of Economic History, 249-270. 
spheres". 3 In the latest technological revolution, "new technologies" include everything from the internet to drone to big data, and the potential application of these technologies are rapidly expanding.

Some aspects on the development of technology, such as nuclear weapons, fishing activities, biotechnology, steam cell, genetic modified organism, artificial super intelligence, are closely linked with social and political concerns. Yet, the divisive effects of the latter are to some extent offset by the desire to overcome the massive challenges of climate, sea, and space, and to dull the ever-growing threat of nuclear weapons. These pressures force nations to cooperate, initially perhaps because of selfinterest, self-preservation, a common adventurous spirit, or a mutual realization that atomistic behavior in certain fields will produce fewer results than collective action. The resulting cooperation programs foster increased contact among nations; more contacts accompanied by good faith performance of assumes obligations should hasten the emergence of a common respect and understanding which may brighten the prospects for future agreements beyond science and technology.

Establishing effective control over scientific and technological pursuits will require both a realistic appraisal of political factors and a process of take and give. Obtaining some measure of international control in the development of a system of communication satellites or climate modification, in the exploration of the sea, or in the limitation or abolition of nuclear weapons, requires a certain loss of

\footnotetext{
3 Klaus Schwab, 'The Fourth Industrial Revolution: What it means, how to respond', (2016) January, World Economic Forum, available at www.weforum.org/agenda/2016/01/the-fourth-
}

sovereignty by each participating nation. But, against this loss must be measured the mutual advantages to be gained from a realistic accommodation of interests.

It is urgent to ensure the role and capacity of International Law to govern and harness the tremendous potential of science and technology. Due recognition of this function is especially warranted at the present time when ambitious hopes and sizeable fears accompany rapid science and technology advances. In this environment, International Law can serve as an organizational mechanism to implement the desire of nations to cooperate. Given the difficulties in the social and political areas of human relations, international cooperation seems more feasible in scientific and technological areas. The prohibitive cost of large-scale scientific programs necessary to ensure efficient progress in diverse field encourages cooperative ventures and sharing information. Moreover, cooperation in social and political sphere is greatly hampered by significant ideological and emotional discord. This friction has precluded agreement upon a substantial number of current international problems and has raised serious obstacles to social or political integration. The aim of the study is to examine the role of International Law in responding to the technological advances.

\section{LEGAL MATERIALS AND METHODS}

It is a normative legal research using primary and secondary legal materials. While the primary legal materials consist of all the international agreement related to the development of technology both directly and 
indirectly, secondary ones included the references, including books, journal articles as well as conference papers and other documents having correlation with the issues. The technique of analysis data used legal interpretation.

Specifically, the international agreements as primary legal materials including: the 1868 St Petersburg Declaration Renouncing the Use, in time of war, of Explosive Projectiles under 400 Grammes Weight; the 1925 Geneva Protocol for Prohibition of Poisonous Gases and Bacteriological Methods of Welfare; the 1972 United Nations Convention on the Prohibition of the Development, Production, and Stockpiling of Bacteriological (Biological) and Toxin Weapons and on their Destruction; the 1993 Convention on the Prohibition of the Development, Production, Stockpiling, and Use of Chemical Weapons; the 1995 Protocol IV to the United Nations Convention on Prohibition or Restrictions on the Use of Certain Conventional Weapons which may be deemed to be excessively injurious or to have indiscriminate effects, on blinding laser weapons 1995; the 1980 United Nations Convention on Prohibition or Restrictions on the Use of Certain Conventional Weapons which may be deemed to be excessively injurious or to have indiscriminate effects; and the 1996 Amended Protocol II to the United Nations Convention on Prohibition or Restrictions on the Use of Certain Conventional Weapons which may be deemed to be excessively injurious or to have indiscriminate effects, on prohibitions or restrictions on the use of mines, booby-traps, and other devices.

\section{RESULTS AND DISCUSSIONS}

The Debate on Regulatory of Technological Advances under International Law: Framing the Issues

Many scholars have claim that technology and regulation can be seen as two contradictory matters. Technology symbolizes markets, enterprise, and growth, while regulation represents government, bureaucracy, and limits to growth. ${ }^{4}$ The modern regulatory era, starting in the 1960 s, the contradiction focused on one side, regulation as mechanism to restrain technological risk while the other side, regulation created hindrance over the progress of new technology. ${ }^{5}$ Moreover, in the 1970s, the debate emphasized on the development of nuclear power, supersonic transport, and food additives. Today, the debate still continues regarding to the fears of electromagnetic field, greenhouse gas emissions, fiber optic, genetically modified foods and so on sparking new calls for precautionary regulation. ${ }^{6}$

In contrary, other scholars have different views regarding this matter. Fist, many have argued that technological advance itself could reduce risk by introducing the excellent new method of production. ${ }^{7}$ There are many newer products and devices are often less dangerous and less polluting that older ones, proving that regulation serve as a mechanism to reduce risks rather than inhibit new technology. Second, many have hypothesized that regulation could improve, rather than impede, businesses innovative

\footnotetext{
6 Ibid.

7 OECD, Innovation and the Environment, OECD Proceeding on Workshop of Innovation and the Environment, 2000, p. 7-9.

4 Jonathan B. Wiener, 'The regulation of technology, and the technology of regulation', (2004) 26 , Technology in Society, 483.

5 Ibid., p. 484.
} 
edge and competitiveness. ${ }^{8}$ In this case, regulation stimulates the firm to conserve resources and switch to cleaner substitutes in ways that actually save the money of firms. Even if such moves are costly to the firm, regulation enables firms in countries that regulate first to take the lead in selling new technologies to countries that follow. ${ }^{9}$

The crucial shortcoming over all the arguments above is the framing of regulation as a single kind of rule or strategy. Regulation is treated as if it comes in one type and has only an effect on technology. Nonetheless in reality, there are many different types of technologies likewise there are many difference kinds of regulations. Difference regulatory instruments such as technology requirements, performance standards, taxes, tradable allowances, and information disclosure, could have very different effects on technological advance and other important consequences. ${ }^{10}$

In a broad sense, technology should not understand as not just hardware or equipment or chips, but as any device or system for converting inputs into outputs for changing the production function. In this context, Wiener asserts that regulation is a technology itself. ${ }^{11}$ It is since regulation is a set of techniques for changing production functions to produce fewer of some outputs, such as pollution, waste, acid rain, or more others. Regulation is technology of governance. ${ }^{12}$ The influence of regulation on technology is critically depend on the technology of

\footnotetext{
${ }^{8}$ M.E. Porter, 'America's Green Strategy', (1991) 264 4, Scientific American 264, 168.

9 Jonathan B. Wiener, op.cit.

${ }^{10}$ Ibid.

${ }^{11}$ Ibid.

${ }^{12}$ Ibid.

13 Rosemary Rayfuse, "Public International Law and the Regulation of Emerging Technologies" in Roger Brownsword et al (Eds), The Oxford
}

regulation. Diversity of regulatory design can hindrance or accelerate technological change, or shape it in varying ways, favoring some kinds of technology over others.

International Law is the system of rules and principles that regulate behavior between international actors. In the context of technological advance, international law has the role to regulate either the development or deployment of emerging technologies in responding to the need to protect the international community from excesses of, possibly catastrophic, and even risks posed by technology. ${ }^{13}$ Since science and technological research is developing in power and capacity to transform not only the global environment, but also humankind itself, on a long term or even permanent basis, International Law is being called upon to proactively develop new form of international regulation and governance capable in anticipating, accessing, minimizing, and mitigating the risks posed by emerging or novel technologies including the risk of their rogue deployment by a state or individual acting unilaterally. ${ }^{14}$ In other words, International Law is being called upon to regulate not just the past and present development and deployment of technologies, but also the uncertain futures these technologies pose.

International Law has the role as an impartial framework or reference for the process of claim and decision. ${ }^{15}$ It seeks to limit the choice of alternative policies and

Handbook of Law, Regulation, and Technology, (Oxford University Press, 2017), 500

14 United Nations Environment Programme (UNEP), 21 Issues for the $21^{\text {st }}$ Century: Results of the UNEP Foresight Process on Emerging Environmental Issues, (UNEP, 2012), 2-3.

15 Tim Hillier, Sourcebook on Public International Law, (Cavendish Publishing Limited, 1998), 1415. 
methods of implementation in order to enhance values shared by most members of the international community and at least, to minimize the disruption of public order over the utilization, allocation and control of technology. ${ }^{16}$ It has to reconcile diverse national interest by means of equitable and rational solutions. To fully this matter, International Law also has to accommodate themselves to the overriding value of efficiency inherent in modern technology. ${ }^{17}$ As problems of allocation and management become more technical in nature, the logic of efficiency will be applied more rigorously.

The role of International Law over an emerging technology remains become subject of debate. On the one hand, International Law provides order and clarity as to the rights and obligations governing the relations between different actor, encourages to promote technological development, and facilitates exchanges of knowledge and goods and of providing framework for peacefully resolving disputes. ${ }^{18}$ On the other hand, regulating uncertainty, unknown, and even unknowable future requires flexibility, transparency, accountability, participation by a whole range of actors beyond the state, and the ability to obtain, understand, and translate scientific evidence into law. ${ }^{19}$ Despite the pretense of its ever-increasing purview over issue of global interest and concern, International Law remains rooted in its Westphalian origin premised on the state sovereignty. This raises kinds of

\footnotetext{
${ }^{16}$ Douglas M. Johnston, 'Law, Technology, and the Sea', (1967) 55, Cal. L. Rev. 449 Available at: http://scholarship.law.barkeley.edu/californialawr eview/vol55/iss $2 / 5$

${ }^{17}$ Ibid.

${ }^{18}$ Rosemary Rayfuse, above n.13 502.

${ }^{19}$ Ibid.

20 Gary D. Solis, The Law of Armed Conflict: International Humanitarian Law in War, (Cambridge University Press, 2010), 38.
}

predicaments including a fragmented and decentralized system of vague and sometimes conflicting norms and rules, uncertainty enforcement, and overlapping and competing jurisdictions and institutions.

\section{International Law as a Regulator over Technological advances}

The history of human development has shown that many technological advances contributed to the development of international law. In the field of international humanitarian law for example, on the one hand, there were new technological discoveries such as gunpowder and cannons, but on the other hand, international humanitarian law prohibits the use of certain technologies that violated humanity values, morality, and civilization. ${ }^{20}$ Indeed, attempts to ban the use of certain weapons are not something new. Toxic weapons have been banned by Muslims, Hindus, Greeks and Romans in ancient times. In the medieval ages, the Lateran Council instructed that the use of crossbow and albalest were considered "unchristian weapon". ${ }^{21}$

The first international approach made by the international community related to the use of new technology, in this case was the technological advance in the field of international humanitarian law, marked by the adoption of the 1868 St Petersburg Declaration on explosive projectiles. ${ }^{22}$ This declaration strictly prohibits the use of exploding bullets. The adoption of this

${ }^{21}$ Adam Roberts and Richard Guelff, Documents on the Laws of War, Third Edition, (Oxford University Press, Oxford, 2000), 3.

${ }^{22}$ The 1868 St Petersburg Declaration Renouncing the Use, In Time of war, of Explosive Projectilles Under 400 Grammes Weight, 11 December 1868, enter into force 11 December 1868, LXVI UKPP (1868) 659. 
Declaration was followed by the adoption of other declarations renouncing specific weapons and means of welfare at the Peace Conference of 1899 and 1907, which eventually led to the international treaties prohibiting the development, production, stockpiling, and use of poison gas $(1925)^{23}$, bacteriological or biological weapons 1972) ${ }^{24}$, chemical weapons $(1993)^{25}$, blinding laser weapons $(1995)^{26}$, and other forms of conventional weapons (1980) $)^{27}$, including certain types of anti-personal land mines (1996). ${ }^{28}$ The latest challenge of international humanitarian law related to technological advances was the creation of cyber weapons and other emerging military technologies, such as unmanned aerial vehicles, directed-energy weapons, and lethal autonomous robots. ${ }^{29}$ The challenge faced by International Humanitarian Law is to ensure that technological advances in the field of Humanitarian Law (including methods and means of war) must be

23 The 1925 Geneva Protocol for the Prohibition of Poisonous Gases and Bacteriological Methods of Walfare, 17 June 1925, enter into force 8 February 1928, XCIV LNTS (1929) 65-74.

24 The 1972 United Nations Convention on the Prohibition of the Development, Production, and Stockpiling of Bacteriological (Biological) and Toxin Weapons and on their Destruction, 10 April 1972, enter into force 26 March 1975, 1015 UNTS 163 (1976).

25 The 1993 Convention on the Prohibition of the Development, Production, Stockpiling, and Use of Chemical Weapons, 3 September 1992, enter into force 29 April 1997, 1974 UNTS 317.

26 The 1995 Protocol IV to the United Nations Convention on Prohibition or Restrictions on the Use of Certain Conventional Weapons Which May Be Deemed to be Excessively Injurious or to Have Indiscriminate Effects, on Blinding Laser Weapons 1995, enter into force 30 July 1998, 35 International Legal Materials 1218 (1996).

27 The 1980 United Nations Convention on Prohibition or Restrictions on the Use of Certain Conventional Weapons Which May Be Deemed to be Excessively Injurious or to Have Indiscriminate regulated in such a way as to maintain human dignity. ${ }^{30}$

Currently, there is no a single legally binding of international agreement to regulate technological advances in order to limit their potential risks. Nevertheless, all states are bound by general principles of law and international customary laws that are compatible with the development and deployment of the technology. General principles and international customary laws include: the basic norms of international peace and security law, such as the prohibition on the use of force and invention in the domestic affairs of other states $;{ }^{31}$ the basic principles of international humanitarian law, such as requirements of humanity, distinction and proportionality; ${ }^{32}$ the basic principles of human dignity and the right to life, liberty and security of the person; ${ }^{33}$ and the basic principles of international environmental law including the obligations to protect vulnerable ecosystems and species, the precautionary principles, and a range of

Effects, 10 October 1980, enter into force 2 December 1983, 1342 UNTS 3.

28 The 1996 Amended Protocol II to the United Nations Convention on Prohibition or Restrictions on the Use of Certain Conventional Weapons Which May Be Deemed to be Excessively Injurious or to Have Indiscriminate Effects, on Prohibitions or Restrictions on the Use of Mines, Booby-Traps and Other Devices, 3 May 1996, enter into force 3 December 1998, 35 International Legal Materials 1206-1217 (1996).

29 Braden R. Allenby, 'Are New Technologies Undermining the Laws of War?' (2014) 70 Bulletin of the Atomic Scientists, 21-31.

30 Rosemary Rayfuse, above n.13, 502.

${ }^{31}$ Christine Gray, International Law and The Use of Force, Third Edition, (Oxford University Press, 2008), 6.

32 Jean-Marie Henckaerts and Louise Doswald-Beck, Customary International Humanitarian Law, Volume 1 Rules, International Committee of the Red Cross, ( Cambridge University Press, 2005), 3.

33 Olivier de Schutter, International Human Rights Law, Second Editions, (Cambridge University Press, 2014), 61-66. 
procedural obligations relating to cooperation, consultation, notification, and exchange of information, environmental impact assessment, and participation. ${ }^{34}$ The general customary rules on state responsibility and liability for harm also apply. ${ }^{35}$ It means that, if the international law is seen as a dynamic process, ${ }^{36}$ so that there is no single legally binding of international law regulates the development of technology, general principles of law as one of the sources of international law constitutes "an authoritative recognition of a dynamic element on international law and of the creative function of courts which may administer $i t "{ }^{37}$ In this condition, general principles have functions, one of which is it could be applied as norms whenever there are no formulated norms governing a given question. ${ }^{38}$

Many new technologies such as nanotechnology and artificial intelligence, remain essentially unregulated by international law. ${ }^{39}$ However, synthetic biology have been discussed by the Conference of the Parties (COP) to the 1992 Convention on Biological Diversity (CBD), where the discussion of the synthetic biology on the conservation and management of

34 Philippe Sands and Jacqueline Peel, Principles of International Environmental Law, Third Editions, (Cambridge University Press, 2012), 117.

35 James Crawford, The International Law Commission's Articles on State Responsibility: Introduction, Text, and Commentaries, (Cambridge University Press, 2002), 1.

36 R. Higgins, Problems and Process: International Law and How We Use It, (Clarendon Press, 2003), 10.

37 J.L. Brierly, The Law of the Nations: An Introduction to the International Law of Peace, (Clarendon Press, 1963), 63.

38 M. C. Bassiouni, 'A Functional Approach to 'General Principles of International Law', (1990) 11 Minch. J. Int'l L. 775-776. Available at: http://repository.law.umich.edu/mjil/vol11/iss3/3 biological diversity. Nevertheless, in 2014, the COP resolved that there are currently synthetic biology and biodiversity issues (CBD COP 2014). Thus, the application of the CBD to synthetic biology remains a matter of discussion and debate within the COP. $^{40}$ Furthermore, in the field of biotechnology, International Law has specifically addressed issues related to biosafety, bioterrorism, and human biotechnology. In regard to biosafety, the Article $8(\mathrm{~g})$ of the CBD has obliged state party to establish or conserve the environmental impacts that could affect the conservation and sustainable use of biological diversity, taking into account the risks to human health. ${ }^{41}$

Moreover, in the field of biotechnology, new technology that also became the consensus of international law is "living modified organism" (LMO). The 2000 Cartagena Protocol provides the definition of LMO as "any living organism that possesses a novel combination of genetic material obtained through the uses of modern biotechnology". ${ }^{42}$ Meanwhile, 'living organism' is defined as 'any biological entity capable of transferring or replicating genetic material, including sterile organisms, viruses

39 Albert C. Lin, "International Legal Regime and Principles Relevant to Geoengineering", in Wil C.G. Burns and Andrew L. Strauss (Eds), Climate Change Geoengineering: Philosophical Perspective, Legal Issues, and Governance Frameworks, (Cambridge University Press, 2013), 182-199.

40 Paul Oldham, Stephen Hall, Geoff Burton, "Synthetic Biology: Mapping the Scientific Landscape", (2012) 7 4, PLOS Onem, 12-14.

${ }^{41}$ Article $8(\mathrm{~g})$ of the 1992 Convention on Biological Diversity, 5 June 1992, enter into force 29 December 1993, 1760 UNTS 79.

42 Article 3 (g) of The 2000 Cartagena Protocol on Biosafety to the Convention on Biological Diversity, 29 January 2000, enter into force 11 September 20013, 39 International Legal Materials 1027 (2000). 
and viroids'. ${ }^{43}$ Thus, LMO includes novel viruses and organisms developed in laboratories. Of course, merely bioengineering LMOs in a laboratory does not constitute 'release'. It does, however, constitute 'use' under the CBD and the more specific definition of 'contained use' in the Cartagena Protocol, which includes "any operation, undertaken within a facility ... which involves LMOs that are controlled by specific measures that limit their contact with, and their impact on, the external environment". ${ }^{44}$ These rules describe that international law recognized new technologies in the field of biotechnology. These provisions do not prohibit the development, use or disposal of LMOs, but rather, this one seeks to ensure 'adequate protection measures' against the risk of unintentional or potentially harmful of LMO release within the transboundary context. If 'adequate measures' are not taken, the States Parties to the CBD and the Cartagena Protocol will be responsible internationally for any potentially transboundary damage resulting from this LMO release. ${ }^{45}$

International Law has strict rules in bioterrorism. The 1972 United Nations Convention on the Prohibition of the Development, Production, and Stockpiling of Bacteriological (Biological) and Toxin Weapons and on their Destruction (hereinafter called as Biological Weapons Convention/BWC) does not only regulate the use and release of biological weapons, but

43 Article 3 (h) of The 2000 Cartagena Protocol on Biosafety to the Convention on Biological Diversity, ibid.

44 Article 11 of The 2000 Cartagena Protocol on Biosafety to the Convention on Biological Diversity, ibid.

${ }^{45}$ Grant Wilson, 'Minimizing Global Catastrophic and Existential Risks from Emerging Technologies through International Law' (2013) 31308 Va. Envtl. L. J. , 338. furthermore, this Convention governs the prohibition of the development, production, stockpiling and acquisition or retention of microbial or other biological agents, or toxins whatever their origin or method of production, of types and in quantities that have no justification for prophylactic, protective or other peaceful purposes. ${ }^{46}$ Moreover, State parties are prohibited from transferring "to any recipient whatsoever, directly or indirectly and from assisting, encouraging, or inducing any stats, group of states or international organizations to manufacture or otherwise acquire any of the agents, toxins, weapons, equipment, and means of delivery banned under the Convention within their territory, jurisdiction, or control". ${ }^{47}$ However, regardless of the use of terminology "prohibition", the application of BWC is still possible for the purposes of prophylaxis, protection, and peaceful purposes as set forth on Article I and X. Even the deadliest biological agents can be developed for peaceful purposes, yet still susceptible to accidental or malicious release. It suggests that although BWC expressly rejects the use of biological agents and toxins as weapons, the states party recognize and accept the value of biological development for peaceful purposes. $^{48}$

International Law also pays great attention to the issue of human dignity in the development of biotechnology and genetic engineering. The Council of Europe's 1977

${ }^{46}$ Article I of the 1972 United Nations Convention on the Prohibition of the Development, Production, and Stockpiling of Bacteriological (Biological) and Toxin Weapons and on their Destruction

47 Article IV of the 1972 United Nations Convention on the Prohibition of the Development, Production, and Stockpiling of Bacteriological (Biological) and Toxin Weapons and on their Destruction

${ }^{48}$ Rosemary Rayfuse, above n. 13505. 
Convention on Human Rights and Biomedicine (CHRB), which prohibits inheritable genetic alterations of humans on the basis of that endangered humanity of all species. Article 13 of the CHRB states that "an intervention seeking to modify the human genome' is not to say any modification in the genome of any descendants". It can be argued that although CBHR is a regional international agreement, with limited participation in the European countries, it is seen that International Law has taken an important (though limited) role in technological advances.

\section{The Capability of International Law and} Its Limitation on Development of Technology

From the discussion before, it could be said that technological advances always bring profound implications for human life, both positive and negative implications. On the one hand, technological advances have the potential to support innovation in products, services and processes; and to help address national and global challenges, including climate change, human population explosions, economic growth, and other environmental pressures. On the other hand, the potential risks posed by technological advances, including misuse of technology, can have negative, even catastrophic, impacts on people and the global environment. ${ }^{49}$ Even, managing and controlling the research and development of emerging technologies would be a daunting task, particularly as, in many cases, the risks posed by some of these technologies will not be understood until

\footnotetext{
${ }^{49}$ Grant Wilson, above n. 45

50 Catherine Brolmann and Janne Nijman, Legal Personality as A Fundamental Concept of International Law, Amsterdam Law School Legal Studies Research Paper No. 2016-43, Amsterdam
}

they have been further developed and possibly even deployed. Under these circumstances, International Law becomes relevant as a regulator for technological advances. However, many limitations exist on international law's capability ${ }^{50}$ to respond to these challenges. In particular, the scope and application of International Law to emerging technologies is subject to a number of structural limitations inherent in the consensual nature of International Law. ${ }^{51}$

In the framework of technological development, the concern of International Law does not lie in its nature, form, development or even deployment. An opinion of the International Court of Justice in its Advisory Opinion on the Threat or Use of Nuclear Weapons (Nuclear Weapons Advisory Opinion), stated: "in the absence of specific treaty obligations freely acceptance by states, the development of nuclear weapons is not prohibited by international law. Indeed, even their use is not unlawful, per se; at least in circumstance where the state of the art faces an existential threat and otherwise complies with the laws of armed conflict". In the same context, the 1976 Convention on the Prohibition of Military or Any Other Hostile Use for Environmental Modification Techniques governs that the development and use of environmental modification technologies is neither regulated nor prohibited under international law, but only their hostile use in the context of an international armed conflict. ${ }^{52}$ In this matter, the principle of state sovereignty permits states to utilize their resources, conduct research, develop and deploy, or

Center for International Law, University of Amsterdam, 2017, p. 1.

${ }^{51}$ Rosemary Rayfuse, above n. 13

${ }^{52}$ Article 1 of The 1976 Convention on the Prohibition of Military or Any Other Hostile Use for Environmental Modification Techniques. 
allow their nationals to research, develop, and deploy technologies as they see fit. ${ }^{53}$

On the contrary, International law has an attention on the potential harmful transboundary effect over human kind, the environment, other states, and the global interests. Under the principle of state sovereignty, all states have an obligation to ensure that all of the activities conducted under their jurisdiction and control do not cause harm to other states It could be an example in the case of Article 4 of the 2000 Cartagena Protocol which applies not to the development of LMOs, but rather to "their transboundary development, handling, transport, use, transfer and release". The other example is in the CBD Article 8 (g) that requires to states to "regulate, manage or control", but does not articulate the specific actions to be taken, leaving the precise measures to be taken to the discretion of each state. ${ }^{54}$ Even, while specific actions are articulated as, for example, in the Cartagena Protocol's requirements relating to risk assessment and risk management, national government of the state has a broad policy to decide whether the risks are acceptable, and thereby to override a negative assessment, based on national protection goals. ${ }^{55}$

Associate with national policy created by each state, International Law recognizes the principle of due diligent. The function of due diligence primarily as a standard of conduct that defines and circumscribes the responsibility of a state in relation to the

\footnotetext{
${ }^{53}$ Rosemary Rayfuse, above n.13, 505.

${ }^{54}$ Grant Wilson, above n. 45, 340.

55 Ibid.

56 Jan Hessbruegge, "The Historical Development of the Doctrines of Attribution and Due Diligence in International Law", (2004) 364 New York University Journal of International Law and Politics, 286.

57 Patricia Birnie, Alan Boyle, and Catherine Redgwell, International Law and the
}

conduct of third parties. ${ }^{56}$ Similarly, in international environmental law, the basic position is that states are not strictly liable for transboundary environmental damage. ${ }^{57}$ Rather, states are required to exercise due diligence to prevent significant transboundary harm emanating from their territory. ${ }^{58}$ In this context for example, due diligent depends on, inter alia, the nature of the specific activities, the technical and economic capabilities of states, the effectiveness of their territorial control, and the state of scientific or technical knowledge (Seabed Mining Advisory Opinion). It is important to note here that as long as the state has acted in accordance with the principle of due diligence, it shall be free from international responsibility for the unintended consequences of technological developments or for unintentional or accidental acts. ${ }^{59}$ In such a situation, as Wilson notes, more notification preventing the global catastrophic or existential harm from occurring. ${ }^{60}$

Other problems relating to the capacity of international legal lie in the formal sources of international law. Although general principle of law and customary international law are binding to all state, yet these only provide a basic framework in which the regulation of development and deployment of technology might take place. Certain obligations covered in international agreement. As it could be seen, making the international agreement is time-consuming

Environment, Third Edition, (Oxford University Press, 2009), 217-218.

58 E.g., International Law Commission (ILC), Draft Article on Prevention of Transboundary Harm from Hazardous Activities, with Commentaries, Doc. A/56/10 (2001), Article 3, paragraph 7.

59 Patricia Birnie, Alan Boyle, and Catherine Redgwell, above n. 57, 146.

${ }^{60}$ Grant Wilson, above n. 45, 342. 
and cumbersome exercises, and moreover, the international agreement is generally focused on regulating specific activities, rather than future one. It means that international agreement is limited in its substantive scope. Besides that, the international agreement is only binding on their parties. ${ }^{61}$ There is no International Law forces a state become a party of the international agreement. In addition, the other problem faced by international law relating to its role in technological advance is the absence of law enforcement mechanisms, even when a state has become a party to international agreement.

Another problem that equally important is the nature of subject involved in the development and deployment of technology. The government of a state is not the only actor involved in the research, development and deployment of technology. These activities were also conducted by individuals (both natural and corporate). However, in order to achieve responsible research, a "governance" is required. Recognizing the influence that private individuals can have in the development of 'governance' regimes, ranging anywhere along the spectrum from voluntary ethical framework involving self-regulation to formal regulatory of legislative measures adopted under national and/or international law. ${ }^{62}$ However, beyond the context of individual responsibility for international crimes, it may not be immediately apparent

${ }^{61}$ Article 34 The 1969 Vienna Convention on the Law of Treaties.

${ }^{62}$ Andrea Bianchi, Non-State Actors and International Law, (Ashgate, New York, 2009), xi.

63 Peter Singer, 'Ethics and the Limits of Scientific Freedom', (1996) 792 The Monist, 223.

${ }^{64}$ Maria Paola Ferretti, 'Risk and Distributive Justice: The Case of Regulating New Technology' (2010) 163 Science and Engineering Ethics 501-515. what role international law can or should play in the regulation of these private actors.

This issue may be displayed by reference to the issue of the role of International Law in the regulation of scientific research. The freedom to pursuit scientific knowledge is regarded as a fundamental right. Although the precise limits of the boundaries remain open to debate, ethical limits to scientific enquiry have been identified where the nature of research is such that the process itself will have potentially adverse impacts on human subjects and non-human animals. ${ }^{63}$ Increasingly, perceptions as to the limits of the right have been influenced by changing conceptions of risks and the increasing recognition of the problem of uncertainty. ${ }^{64}$ This changing perceptions have given rise to legal regulation in some circumstance and, as analysis of the development of regulation of nuclear weapons and research on the human genome demonstrates that the presumption in favour of a freedom of gaining knowledge over prohibiting research only operates where the research is conducted "responsibly" and for "legitimate scientific purposes". ${ }^{65}$ What constitutes "responsible" and "legitimate scientific research" depend not only on an assessment of scientific plausibility, but also on its desirability within the larger social development context, ${ }^{66}$ and on its compliance with international legal norms. In this respect, international law can play a role in both articulating and in

\footnotetext{
65 Jack Stilgoe, Richard Owen, and Phil Macnaghten, 'Developing a Framework for Responsible Innovation', (2013) 429 Research Policy, 15681580.

${ }^{66}$ Adam Corner and Nick Pidgeon, 'Geoengineering the Climate: The Social and Ethical Implication', (2010) 521 Environment: Science and Policy for Sustainable Development, 26.
} 
harmonizing the legal content of due diligent standards for what constitutes "responsible" or "legitimate scientific research" and in establishing mechanisms and institutions by or in which assessments of legitimacy and desirability can take place at the global level.

\section{CONCLUSIONS AND SUGGESTIONS}

As a regulator of technological advances, International Law, despite its limitations, should have a role to play in regulating its development and use. Many facts showed that International Law could reconcile the technological advances.
In order to enhance understanding of many interfaces between technological advances and law, especially international law, it is better to improve the chances of putting in place an international regulatory environment that stimulates technologies contributing to the human flourishing and at the same time, minimizing application that are unacceptable. One of the accomplishments is through applying the general principles of law whenever there are no regulated norms in any disputes regarding to the technological advances.

\section{REFERENCES}

\section{Books}

Bianchi, Andrea, Non-State Actors and International Law, (New York: Ashgate, 2009)

Birnie, Patricia; Alan Boyle, and Catherine Redgwell, International Law and the Environment, Third Edition, (Oxford: Oxford University Press, 2009)

Brierly, J. L. The Law of the Nations: An Introduction to the International Law of Peace. (Clarendon Press, 1963)

Brolmann, Catherine and Janne Nijman, Legal Personality as A Fundamental Concept of International Law. Amsterdam Law School Legal Studies Research Paper No. 2016-43, (Amsterdam Center for International Law, University of Amsterdam, 2017). Crawford, James, The International Law Commission's Articles on State Responsibility: Introduction, Text, and Commentaries, (United Kingdom: Cambridge University Press, 2002)

Hillier, Tim, Sourcebook on Public International Law. London, (Sydney: Cavendish Publishing Limited, 1998)
Gray, Christine, International Law and The Use of Force, Third Edition, (Oxford: Oxford University Press, 2008)

Henckaerts, Jean-Marie and Louise Doswald-Beck, Customary International Humanitarian Law, Volume 1 Rules, International Committee of the Red Cross. (United Kingdom: Cambridge University Press, United Kingdom, 2005)

Higgins, R., Problems and Process: International Law and How We Use It, (Oxford: Clarendon Press, 2003)

Lin, Albert C. "International Legal Regime and Principles Relevant to Geoengineering", in Wil C.G. Burns and Andrew L. Strauss (Eds), Climate Change Geoengineering: Philosophical Perspective, Legal Issues, and Governance Frameworks, (New York: Cambridge University Press, 2013)

OECD, Innovation and the Environment, (Paris: OECD Proceeding on Workshop of Innovation and the Environment, 2000) 
Rayfuse, Rosemary, "Public International Law and the Regulation of Emerging Technologies" in Roger Brownsword et al (Eds), The Oxford Handbook of Law, Regulation, and Technology, (United Kingdom: Oxford University Press, 2017)

Sachs, Jeffry D., The Age of Sustainable Development, (New York: Columbia University Press, 2015)

Sands, Philippe and Jacqueline Peel, Principles of International Environmental Law, Third Editions (United Kingdom: Cambridge University Press, 2012).

Schutter, Olivier de., International Human Rights Law, Second Editions, (Cambridge University Press, United Kingdom, 2014)

Roberts, Adam and Richard Guelff, Documents on the Laws of War, Third Edition, (Oxford: Oxford University Press, 2000)

Solis, Gary D, The Law of Armed Conflict: International Humanitarian Law in War, (New York: Cambridge University Press, 2010)

\section{Journal Articles}

Allenby, Braden R. "Are New Technologies Undermining the Laws of War?" (2014) 70 Bulletin of the Atomic Scientists.

Bassiouni, M. C. “A Functional Approach to 'General Principles of International Law'", (1990) 11 Minch. J. Int'1 L. 768, Available at: http://repository.law.umich.edu/mjil/v ol11/iss $3 / 3$

Corner, Adam and Nick Pidgeon, 'Geoengineering the Climate: The Social and Ethical Implication', (2010)
521 Environment: Science and Policy for Sustainable Development.

Ferretti, Maria Paola, 'Risk and Distributive Justice: The Case of Regulating New Technology' (2010) 163 Science and Engineering Ethics.

Hessbruegge, Jan., 'The Historical Development of the Doctrines of Attribution and Due Diligence in International Law', (2004) 364 N Y Univ J Int Law Polit.

Hoppit, Julian, 'Understanding the Industrial Revolution', (1987) $30 \quad 1$ The Historical Journal.

International Law Commission (ILC), Draft Article on Prevention of Transboundary Harm from Hazardous Activities, with Commentaries, Doc. A/56/10 (2001).

Johnston, Douglas M., 'Law, Technology, and the Sea', (1967) 44955 Cal. L. Rev. Available at: http://scholarship.law.barkeley.edu/cal ifornialawreview/vol55/iss2/5.

Oldham, Paul; Stephen Hall; Geoff Burton, 'Synthetic Biology: Mapping the Scientific Landscape', (2012) 74 PLOS One.

Porter, Michael E., 'America's Green Strategy', (1991) 2644 Scientific American.

Schwab, Klaus, 'The Fourth Industrial Revolution: What it Means, how to Respond', World Economic Forum, January 14, 2016, available at www.weforum.org/agenda/2016/01/th e-fourth-industrial-revolution-what-itmeans-and-how-to-respond.

Singer, Peter, 'Ethics and the Limits of Scientific Freedom', (1996) 792 The Monist.

Stilgoe, Jack; Richard Owen, and Phil Macnaghten, 'Developing a 
Framework for Responsible Innovation', (2013) 429 Research Policy.

Vries, Jan De, 'The Industrial Revolution and the Industrious Revolution', (1994) 54 2 The Journal of Economic History.

Wiener, Jonathan B., 'The regulation of technology, and the technology of regulation', (2004) 26 Technology in Society.

Wilson, Grant., 'Minimizing Global Catastrophic and Existential Risks from Emerging Technologies through International Law' (2013) 31 Va. Envtl. L. J. 308 .

\section{Conventions}

The 1868 St Petersburg Declaration Renouncing the Use, In Time of war, of Explosive Projectilles Under 400 Grammes Weight, 11 December 1868, enter into force 11 December 1868 , LXVI UKPP (1868) 659.

The 1925 Geneva Protocol for the Prohibition of Poisonous Gases and Bacteriological Methods of Walfare, 17 June 1925, enter into force 8 February 1928, XCIV LNTS (1929) 65-74.

The 1969 Vienna Convention on the Law of Treaties, 23 May 1969, enter info force 27 January 1980, 1155 UNTS 331.

The 1972 United Nations Convention on the Prohibition of the Development, Production, and Stockpiling of Bacteriological (Biological) and Toxin Weapons and on their Destruction, 10 April 1972, enter into force 26 March 1975, 1015 UNTS 163 (1976).

The 1976 Convention on the Prohibition of Military or Any Other Hostile Use for Environmental Modification Techniques.
The 1980 United Nations Convention on Prohibition or Restrictions on the Use of Certain Conventional Weapons Which May Be Deemed to be Excessively Injurious or to Have Indiscriminate Effects, 10 October 1980, enter into force 2 December 1983, 1342 UNTS 3.

The 1992 Convention on Biological Diversity, 5 June 1992, enter into force 29 December 1993, 1760 UNTS 79.

The 1993 Convention on the Prohibition of the Development, Production, Stockpiling, and Use of Chemical Weapons, 3 September 1992, enter into force 29 April 1997, 1974 UNTS 317.

The 1995 Protocol IV to the United Nations

Convention on Prohibition or Restrictions on the Use of Certain Conventional Weapons Which May Be Deemed to be Excessively Injurious or to Have Indiscriminate Effects, on Blinding Laser Weapons 1995, enter into force 30 July 1998, 35 International Legal Materials 1218 (1996).

The 1996 Amended Protocol II to the United Nations Convention on Prohibition or Restrictions on the Use of Certain Conventional Weapons Which May Be Deemed to be Excessively Injurious or to Have Indiscriminate Effects, on Prohibitions or Restrictions on the Use of Mines, Booby-Traps and Other Devices, 3 May 1996, enter into force 3 December 1998, 35 International Legal Materials 1206-1217 (1996).

The 2000 Cartagena Protocol on Biosafety to the Convention on Biological Diversity, 29 January 2000, enter into force 11 September 20013, 39 International Legal Materials 1027 (2000). 
United Nations Environment Programme

(UNEP). 2012. 21 Issues for the $21 \mathrm{st}$

Century: Results of the UNEP

Foresight Process on Emerging

Environmental Issues. Nairobi, Kenya:

UNEP. 